\title{
Analysis and comment
}

\section{Professional regulation \\ Role of systematic reviews in detecting plagiarism: case of Asim Kurjak}

\author{
Iain Chalmers
}

Plagiarism is difficult to detect, especially if it occurs in journals with a small readership. Systematic reviews can help to identify cases, but as this case shows, unless perpetrators face greater sanctions the problem is unlikely to go away

James Lind Library, Oxford OX2 7LG

Iain Chalmers

editor

ichalmers@

jameslindlibrary.org

BMJ 2006;333:594-7
An editorial published in Nature two years ago noted that journals and universities do not always respond appropriately to plagiarism. ${ }^{1}$ The case study reported here shows how these institutional failings can lead to recurrent plagiarism and how institutions and journals can help to reduce it.

\section{Detection}

During a search for studies that might be eligible for inclusion in a systematic review of controlled trials of epidural analgesia in labour in the late 1980s, ${ }^{2}$ I identified a paper by Asim Kurjak and John Beazley published in Acta Medica Iugoslavica. ${ }^{3}$ Well over half of the text and some of the data in this paper were identical to material in an unacknowledged paper published three years earlier by other authors in the Journal of Obstetrics and Gynaecology of the British Commonwealth. ${ }^{4}$ In correspondence, I learnt that these authors had not been contacted by Professors Kurjak or Beazley.

Professors Kurjak and Beazley had both worked at Queen Charlotte's Hospital in London, but the paper purported to be a report of a clinical trial done in Croatia. I first wrote to the British author, Professor Beazley. In a letter sent to me on 25 February 1991 Professor Beazley expressed his surprise and dismay because he had never seen the paper bearing his name. He requested an explanation from Professor Kurjak, now professor of obstetrics at the University of Zagreb, who wrote to me on 26 February 1991 confirming that Professor Beazley had not been involved in the paper. Professor Kurjak's letter to me made no comment on his obviously plagiarised text.

In the report of our systematic review of epidural analgesia in labour, my coauthor and I stated that we had excluded the Kurjak and Beazley article "because it contained long passages of text, and some data, which were identical to material published three years previously in an unacknowledged article by different authors."

\section{Reporting}

Because Professor Kurjak had failed to explain the plagiarism, I reported our findings to those whom I thought should investigate it. The editor in chief of Acta Medica Iugoslavica, Nikola Peršić, writing from the Croatian Academy, concluded his letter to me:

As a colleague and psychiatrist I believe that the stated problem should be solved in the way which would not harm (the) professional and scientific reputation and respect which Prof. Kurjak has earned in 16 years since the problem paper has been published. (10 June 1991).

I wrote to Stojan Knećeviž, Professor Peršić's successor as editor of Acta Medica Iugoslavica (now renamed Acta Medica Croatica), requesting a copy of any notice placed in the journal to draw attention to the plagiarism, but I have never received any response to my request.

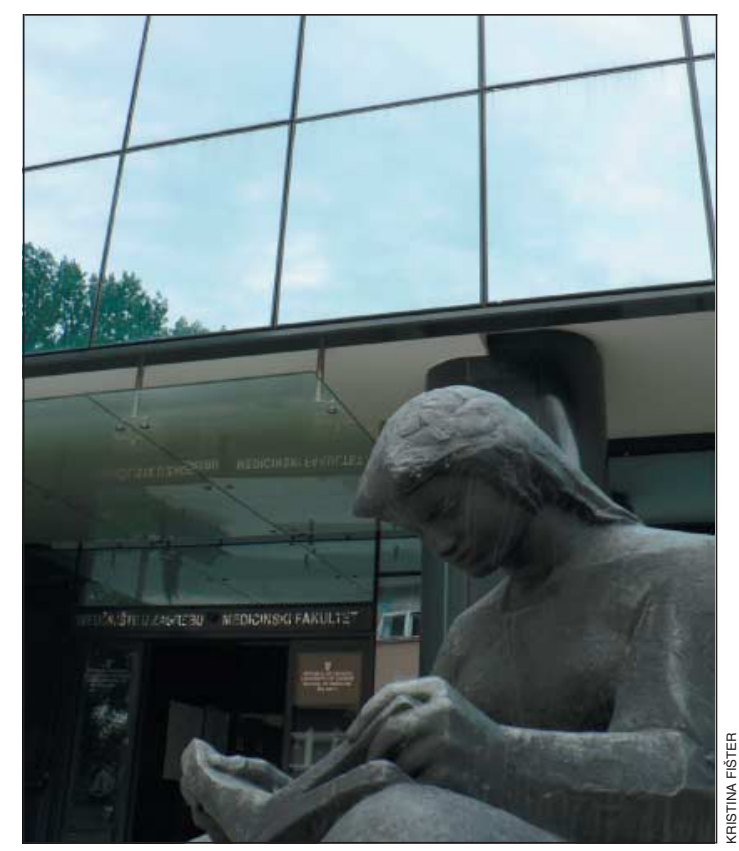

The medical school at the University of Zagreb, where Asim Kurjak is professor of obstetrics 
Because Professor Kurjak was the director of a World Health Organization collaborating centre in medical ultrasonography, I also reported my findings to WHO. WHO reacted by withdrawing sponsorship for an international conference on ultrasonography that Professor Kurjak was organising; transferring the meeting of the editorial board of the Manual on Ultrasound Diagnostics from Zagreb to Geneva, and excluding Professor Kurjak from it; and suspending him from the directorship of the WHO collaborating centre for a year, while the centre was monitored (Marsden Wagner, European Regional Office of WHO, personal communication, October 1991).

Finally, I also reported my findings to the dean of the medical school of the University of Zagreb, Mate Granić. He appointed a special committee to look into the matter, consisting of the vice-deans for science, graduate courses, and external studies. His letter to me on 14 June 1991 reported:

The members of this committee have immediately realized the impact of Dr Kurjak's early days mistake on the universal scientific principles. However, we are pleased to see that Prof. Kurjak is fully aware of his mistake... Since Prof. Kurjak is [a] very distinguished expert in the field with significant contributions to our ultrasound medicine, we would appreciate your tactful handling of this case.

\section{Further evidence}

I now greatly regret having acquiesced in this request for tactful handling of Professor Kurjak's misconduct. Four years ago it was discovered ${ }^{5}$ that Professor Kurjak had plagiarised material from a Norwegian $\mathrm{PhD}$ thesis ${ }^{6}$ and published it as a book chapter coauthored with a Croatian colleague. ${ }^{7}$ A copy of the thesis had been given to Professor Kurjak two years previously by its author (H-G Blaas, personal communication). After the publishers of the book had been informed of the plagiarism, they stopped distribution of the book and republished it without Professor Kurjak's chapter. Professor Kurjak and his coauthor did not deny the accusations of plagiarism but tried to play down their "errors of judgment" (H-G Blaas, personal communication).

The plagiarised Norwegian author and his $\mathrm{PhD}$ supervisor (Blaas and Eik-Nes) informed the executive committee of the International Society for Ultrasound in Obstetrics and Gynecology, which decided that Professor Kurjak and his coauthor would be "ineligible for membership of the Society and associated benefits for a further three years" (Karel Maršál, personal communication). The Norwegian investigators also reported Kurjak's plagiarism to the then dean of the medical school at the University of Zagreb, Boris Labar, in March 2002 but they have not so far received any response.

The example of Professor Kurjak's plagiarism that I identified occurred more than a quarter of a century ago. Thanks to an astute referee of an earlier draft of this article, the plagiarism turns out to have been even more blatant than I had thought. In his comments, the referee, Jim Neilson observed:

The 1974 Acta Med Iug paper... is clearly an amalgam of two papers-one of which is, as pointed out by Iain Chalmers, the 1971 paper by Noble et al in J Obstet Gynaecol Br Cilth 78:559-63. I have done a little detective work and the maternal acid-base work has been lifted from Pearson and
Davies, J Obstet Gynaecol Br Cwlth 1973;80:218-24. As with the Noble paper, large parts of the text have been used verbatim, with little modification, and with no acknowledgement of the Pearson and Davies paper... The figures in the tables have been modified slightly from both original papers, in the Kurjak and Beazley paper-so this is not only plagiarism, it is also scientific fraud."

\section{Action}

More than 15 years have passed since I detected Professor Kurjak's plagiarism and reported it to the relevant authorities. Yet, as the Norwegian case shows, he seems to believe that he can continue to act with impunity in this respect. This continued scientific misconduct raises serious doubt about the extent to which his publications are trustworthy accounts of his own work. Despite this record of scientific misconduct, Professor Kurjak is clearly regarded with great respect, not only within Croatia but also by many obstetricians elsewhere.

The case I have described is an illustration of a more widespread problem. What could or should a whistleblower like me expect from institutions and journals when plagiarism is reported to them. I can illustrate some general principles by itemising my current expectations in this case:

- The University of Zagreb should take steps to check or ensure that the 243 publications currently listed in Medline with A Kurjak as an author can be shown to be trustworthy accounts of Professor Kurjak's work

- The University of Zagreb should make publicly available, in English, an account of the methods, findings, and conclusions of its investigation

- The university should send the results of its investigation to all the journals and editors of books containing publications by Professor Kurjak, to those who have purportedly coauthored articles with him, and to all the officers of the International Society for Ultrasound in Obstetrics and Gynecology

- Journals containing articles of dubious authenticity authored by Professor Kurjak should publish notices drawing attention to these concerns and notify the relevant bibliographic databases (the Medline record (PMID: 4820193) of the 1974 Kurjak and Beazley article published in Acta Medica Iugoslavica has no annotation, only a list of 10 related articles).

This case happens to report instances of plagiarism by a Croatian author, currently a senior member of staff in the University of Zagreb, and involves a Croatian journal. But the case should not be taken to reflect badly on Croatian researchers, Croatian institutions, or Croatian journals in general. For example, the Croatian Medical Journal, which has not featured in any part of this case, clearly takes research integrity much more seriously than most journals do. ${ }^{8}$

\section{Naming and shaming}

Although this is but one case study, it prompts me to make some general suggestions for detecting and reducing plagiarism. Firstly, journals and institutions should heed Nature's editorial call ${ }^{1}$ to take allegations of plagiarism more seriously than they seem to at present. Secondly, as has been suggested by Tom Jefferson and colleagues, ${ }^{910}$ journals should use systematic reviews for editorial peer review, as well as 


\section{Summary points}

Journals and institutions should take allegations of plagiarism more seriously

Journals should use systematic reviews for editorial peer review, as well as considering using software designed to detect plagiarism

To reduce the numbers of new as well as recurrent plagiarists, journals, institutions, and professional associations need to expose very publicly those found guilty of plagiarism

considering using software designed to detect plagiarism. Lastly, to reduce the numbers of new as well as recurrent plagiarists, journals, institutions, and professional associations need to expose very publicly those found guilty of this form of scientific misconduct.

I thank Harm-Gerd Blaas for providing documents showing Professor Kurjak's plagiarism of reports of Norwegian research and, along with Sturla Eik-Nes, Karel Maršál, Jim Neilson, and Vedran Katavić (the Croatian Medical Journal's research integrity editor), for checking the accuracy of earlier drafts of my manuscript.

Contributors and sources: This article is based on the journal articles cited and correspondence with all but one (Professor Boris Labar) of the people named in the text.

Competing interests: None declared.

1 Complacency about misconduct. Nature 2004;427:1.

2 Howell C, Chalmers I. A review of prospectively controlled comparisons of epidural with non-epidural forms of pain relief during labour. Int Obstet Anesth 1992;1:93-110.

3 Kurjak A, Beazley JM. The effect of continuous lumbar epidural analgesia on the fetus, newborn child and the acid-base status of maternal blood. Acta Med Iugosl 1974;28:15-26.

4 Noble AD, Craft IL, Bootes JA, Edwards PA, Thomas DJ, Mills KI. Continuous lumbar epidural analgesia using bupivicaine: a study of the fetus and newborn child J Obstet Gynaecol Br Commonw 1971;78:559-63.

Blaas H-GK. Scientific misconduct. Gynekologen 2002;15:37-40.

6 Blaas H-CK. The embryonic examination. Ultrasound studies on the Blas H-GK. The expryonic examination. Ultrasound studies on the . Trondheim: Norwegian University of Science Technology, 1999

Kurjak A, Kupesic S. Ultrasound of first trimester CNS development: structure and circulation. In: Levene M, Chervenak F, Whittle M, eds. Fetal and neonatal neurology and neurosurgery. 3rd ed. London: Harcourt, 2001:39-44. [Withdrawn.]

8 Katavić V. Five-year report of Croatian Medical Journal's research integrity editor-policy, policing, or policing policy. Croat Med J 2006;47:220-7.

Jefferson T, Deeks J. The use of systematic reviews for editorial peer reviewing: a population approach. In: Godlee F, Jefferson T, eds. Peer review in health sciences. London: BMJ Books, 1999:224-34.

10 Jefferson T, Shashok K. Journals: how to decide what's worth publishing. Nature 2003;421:209-10.

(Accepted 26 June 2006)

doi $10.1136 /$ bmj.38968.611296.F7

\title{
Commentary: Ethical writing should be taught
}

\author{
Miguel Roig
}

St John's University, 300 Howard Avenue, Staten Island, NY 10301, USA

Miguel Roig associate professor of psychology

roigm@stjohns.edu
Iain Chalmers describes a case of scientific misconduct in which an author plagiarised both text and data on two separate instances. ${ }^{1}$ Although he took the proper steps after detecting the plagiarism, Chalmers seems to have been unsuccessful in resolving the matter. This and other similar failures of our scientific system of justice leads me to support his recommendations for dealing with plagiarism, particularly his call to publicly expose those who have been found guilty of misconduct.

Public exposure of plagiarists, and the consequent embarrassment and ostracism that these offenders should experience, not only satisfies our intrinsic need for social justice but can also serve as a deterrent. Unfortunately, many scientific journals, professional organisations, and academic institutions lack the necessary resources and, apparently in some cases, even the will to investigate misconduct allegations.

\section{What constitutes plagiarism?}

To make matters worse, plagiarism can be an ill defined and complex concept. For example, some evidence suggests that many health educators do not consider self plagiarism to be unethical. ${ }^{2}$ Other evidence shows that doctors do not always agree about whether certain forms of writing constitute plagiarism. ${ }^{3}$ Consider the practice of paraphrasing. When asked to paraphrase easy to read text without committing plagiarism most students and professors have little difficulty rewriting the material and providing adequate paraphrases. ${ }^{45}$ However, when asked to paraphrase complex technical text, many students, ${ }^{4}$ and some professors, ${ }^{5}$ tend to simply change a word here or there, a practice that some journal editors interpret as plagiarism. ${ }^{6}$

Writing scholarly or scientific journal articles can be demanding. Manuscripts are expected to be not only technically sound but concise and clear while incorporating appropriate terminology. Many scientists will take several years to develop the appropriate writing style and, even when they master it, still find writing an arduous task. Thus, the allure of misappropriating portions of others' text with little or no modifications can be quite strong for some authors, especially those with less than a full command of written English.

Perhaps because much scientific writing uses unique terminology and phraseology, some definitions of plagiarism allow for minor copying of methods sections. ${ }^{7}$ When rewriting a description of a highly technical, detailed procedure authors run the risk of altering the meaning in a way that may make replication of an experiment difficult or impossible. Such an outcome would be highly undesirable in the sciences. On the other hand, over-reliance on copying and pasting of methods sections has its own risks, such as the omission of important new details or the inclusion of minor subtleties that are not applicable in the new context. Some evidence exists that copying and pasting can lead to errors in electronic medical charts. ${ }^{8}$ Perhaps for similar reasons, at least one journal has cautioned against copying and pasting methods sections. ${ }^{9}$ 